\title{
INKLUSIWITEIT AS EVANGELIE
}

\section{Author:}

Ernest van Eck ${ }^{1}$

\section{Affiliation:}

${ }^{1}$ Departement Nuwe

Testamentiese Studies,

Universiteit van Pretoria, Suid-Afrika

\section{Correspondence to:}

Ernest Van Eck

e-mail:

ernest.vaneck@up.ac.za

\section{Postal address:}

Departement Nuwe

Testamentiese Studies,

Fakulteit Teologie,

Universiteit van Pretoria,

Lynnwoodweg, Hatfield

0083, Suid-Afrika

\section{Keywords:}

etniese identiteit; inklusiewe ekklesiologie; kuturele identiteit etnisiteitsteorieë;

evangelie

\section{Dates:}

Received: 30 June 2009

Accepted: 21 Aug. 2009

Published: 10 Nov. 2009

How to cite this article:

Van Eck, E., 2009,

'Inklusiwiteit as

evangelie', HTS Teologiese

Studies/Theological Studies

65(1), Art. \#304, 10 pages.

DOI: 10.4102/hts.v65i1.304

\section{This article is available}

at:

http://www.hts.org.za

(c) 2009. The Authors. Licensee: OpenJournals Publishing. This work is licensed under the Creative Commons Attribution License.

\section{ABSTRACT \\ Inclusivity as gospel}

In antiquity, group identity was based on cultural ethnicity. Groups used their ethnicity to define and delineate themselves as unique. Ethnicity was determined by characteristics like family (kinship), name, language, homeland, myths of common ancestry, customs, shared historical memories, phenotypical features, and religion. The Jewish temple religion and law-abiding Jews in the early church (as depicted in Acts and the congregations of Paul) also used their ethnic identity as argument for justifying the exclusion of other groups/ethnic peoples from the Temple and the early church, respectively. Jesus, Acts and Paul, on the contrary, proclaimed that ethnicity meant nothing when it comes to being in God's presence, being part of the early Christ-followers, or being part of any local (Pauline) congregation. For this reason, it can be concluded that the New Testament bears witness to an inclusive ecclesiology.

\section{INLEIDENDE OPMERKINGS}

In die antieke wêreld het groepe hulleself aan die hand van etnisiteit van ander groepe onderskei. Identiteit is deur (kulturele) etnisiteit bepaal. Bepaalde etnisiteitsmerkers is hiervoor ingespan, te wete familie, naam, taal, land van herkoms, 'n gemeenskaplike voorgeslag, kulturele gebruike, gedeelde geskiedenis, fenotipiese eienskappe, en godsdiens. Die Joodse tempelgodsdiens, Joodse wetsgehoorsame gelowiges in die vroeë kerk (Handelinge) en wetsgehoorsame Joodse gelowiges in van Paulus se gemeentes het op grond van hulle etniese identiteit geoordeel dat persone uit ander etnisiteite van die teenwoordigheid van God (tempelgodsdiens), die Christusgelowiges (Handelinge), of die gemeente (Paulus) uitgesluit moes word. Jesus, Handelinge en Paulus verkondig hierteenoor ' $n$ inklusiewe ekklesiologie: Etnisiteit mag nie bepaal of 'n mens aan God of tot die gemeentes van die Christusgelowiges kan behoort nie. Die Nuwe Testament getuig dus van ' $n$ inklusiewe ekklesiologie.

\section{VERSKILLENDE GROEPE IN DIE NUWE TESTAMENT}

In die evangelies, Handelinge en die briewe van Paulus word daar dikwels na verskillende groepe mense verwys. In die evangelies is Jesus gereeld in konflik met groepe soos die Fariseërs, die skrifgeleerdes, die Sadduseërs en die familiehoofde. Ál hierdie groepe was deel van die Jodedom in die eerste-eeuse Palestina. Jesus het self ook sy eie groep volgelinge gehad wat uit die dissipels en ander volgelinge heel waarskynlik ook Jode - bestaan het. ${ }^{1}$ Jesus was by geleentheid in kontak met 'n Griekse vrou uit Siro-Fenisië (Mark 7:26) en 'n Kanaänitiese vrou uit die gebiede van Tirus en Sidon (Matt 15:21-22). Die Samaritane as groep is ook aan ons welbekend (kyk Matt 10:5; Luk 10:33; Joh 4:7), asook die Grieke (kyk bv Joh 12:20).

Ook in Handelinge kan verskillende groepe aangetoon word: 'mense wat nie Jode is nie' (Hand 11:18; NAV), 'mense wat vantevore uit die heidendom tot die Jodedom oorgegaan het' (Hand 13:43; NAV), 'die Griekssprekendes' (Hand 11:20; NAV), heidene (Hand 13:48), heidennasies (Hand 15:7), persone wat vleis geëet het wat aan 'n afgod geoffer is (Hand 15:29), en die Jode (Hand 11:19; 12:3; 14:2). Hierdie verskillende groepe kan heel waarskynlik tot twee groepe gereduseer word, te wete (wetsgehoorsame) Joodse gelowiges (Hand 11:2), en persone wat nie Jode was nie en tot inkeer gekom het (Hand 11:18), oftewel die woord van God aangeneem het (Hand 11:1).

In die briewe van Paulus lees ons veral van twee groepe, te wete die Jode en nie-Jode (vgl bv Gal 2:7-8; 3:28 [Jode en Grieke]; 1 Kor 1:24; 10:32 [Jode en Grieke]). In Filippense 3:2 is daar ' $n$ aanduiding van ' $n$ groep, heel waarskynlik Jode (Judeërs), wat daarop aangedring het dat die gelowiges in Filippi (heel waarskynlik nie-Jode) hulle moes besny. In 2 Korintiërs 11:21-23 tref ons ' $n$ groep aan wat die werk van Paulus in Korinte teengestaan het - 'n groep wat hulleself ook as apostels beskou het en deur Paulus as 'Hebreërs' en 'Israeliete' beskryf word wat 'van Abraham' afstam. In Romeine 14-15 beskryf Paulus twee konkurrente groepe in die gemeente met die woorde 'sterkes' en 'swakkes' - heel waarskynlik wetsvrye nie-Joodse gelowiges en wetsgehoorsame Joodse gelowiges onderskeidelik. ${ }^{2}$ Hierdie twee groepe vind ons ook in 1 Korintiërs (kyk 1 Kor 8:4-13).

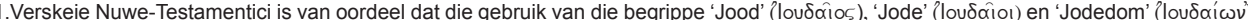
anakronisties is as verwysings na die Jode (persone) en Jodedom (godsdiens) in eerste-eeuse Palestina (kyk bv Pilch 1997:119-125;

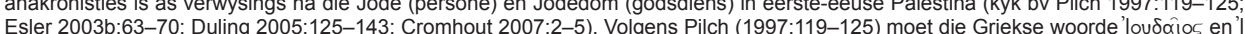
oudaí $\omega v$ onderskeidelik met 'Judeër' en 'Judeanisme' vertaal word, aangesien dit die benaming is wat die Israeliete in die tydperk van oud $\alpha i \omega \nu$ onderskeidelik met 'Judeër' en 'Judeanisme' vertaal word, aangesien dit die benaming is wat die Israeliete in die tydperk van
die Tweede Tempel ( $520 \mathrm{vC}-70 \mathrm{nC}$ ) aanvaar het. Die begrippe 'Jood' en 'Jodedom', daarenteen, se wortels lê in die $6^{\text {de }}$ eeu met die die Tweede Tempel ( $520 \mathrm{vC}-70 \mathrm{nC}$ ) aanvaar het. Die begrippe 'Jood' en 'Jodedom', daarenteen, se wortels lê in die $6^{\text {de }}$ eeu met die
ontstaan van die Rabbynse Jodedom. Esler (2003b:63) toon verder aan dat dit in die antieke tyd die gebruik was om persone of etniese ontstaan van die Rabbynse Jodedom. Esler (2003b:63) toon verder aan dat dit in die antieke tyd die gebruik was om persone of etniese groepe met hulle plek van herkoms te verbind: Persone van Judea sou dus as Judeërs bekend gestaan het. Hoewel hierdie interpretasie in die onderhawige bydrae aanvaar word, sal daar tog van die terme 'Jood', 'Jode' en 'Jodedom ' gebruik gemaak word om die bedoelde teikengroep van die onderhawige bydrae in ag te neem. Wanneer die terme 'Jood', 'Jode' en 'Jodedom 'gebruk word, word daar dus wat godsdienstig en kultureel-etnies met Judeanisme (etniese bande met Judea, en gekoppel aan die tempel in Judea [Jerusalem]) verbind kan word.

2.Die gemeente in Rome het uit nie-Jode (Rom 16) en Jode (Rom 1-3; kyk veral Rom 1:16 en 3:9) bestaan. Romeine 14 en 15 beskryf hierdie twee groepe nader: Aan die een kant is daar hulle (die 'wat sterk is in die geloof'; Rom 15:1, NAV) wat oordeel dat' $n$ mens alles (vis) kan eet (Rom 14:2, 21) (Vleis) kan eet (Rom 14.2, 21), wyn kan drink (Rom 14:21) en alle dae as ewe belangrik kan beskou (heel waarskynlik nie die Sabbat (vis) Sabbat) belangriker ag as ander dae (Rom 14:5). Weens beperkte ruimte sal daar in die onderhawige bydrae nie aan hierdie konflik in die gemeente in Rome aandag gee nie. 


\section{KULTURELE IDENTITEIT}

\section{'n Inleiding tot etnisiteit}

Wat was die identiteit van hierdie groepe? Volgens Holland, Lachicotte, Skinner en Cain (2003:5) kan die begrip 'identiteit' gedefinieer word as 'a concept that figuratively combines the intimate or personal world with the collective space of cultural forms and social relations' (eie beklemtoning). Lieu (2004:12), op haar beurt, is van oordeel dat die identiteit van 'n groep te make het met 'ideas of boundedness, of sameness and difference, of continuity, perhaps a degree of homogeneity, and of recognition by self and by others'. Hierdie omskrywings van identiteit toon dat die identiteit van groepe in wese te make het met dit wat ons etnisiteit kan noem. ${ }^{3}$

In den brede is etnisiteit 'a form of social identity, referring to a collectivity of individuals who ascribe to themselves and/or by others, a sense of belonging and a common cultural tradition (Cromhout 2007:82; eie beklemtoning), '[it] is about cultural differentiation ... concerned with culture ... both collective and individual, externalized in social interaction and internalized in personal self-identification' (Jenkins 1997:165; eie beklemtoning). ${ }^{4}$ Etnisiteit het dus in wese met kultuurverskille te make - vandaar die begrip 'kulturele etnisiteit ${ }^{5}$ wat die meeste navorsers wat die verskille tussen groepe bestudeer, gebruik. ${ }^{6}$

3.Die woord/begrip 'etnisiteit' is in 1942 deur die sosioloog W.L. Warner geyk, en is die eerste keer in 1953 as naamwoord in die Oxford English Dictionary opgeneem. Die

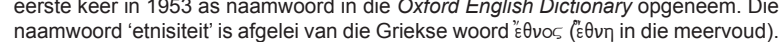

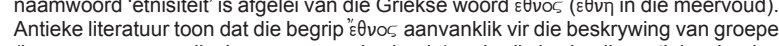
(bv mans, vroue, die inwoners van 'n dorpie) gebruik is. In die antieke Joodse literatuur word "' $\theta$ vos gebruik om op 'n neutrale wyse na groepe mense ('nasies') te verwys - soms as aanduiding van die Jode (Judeërs) as groep (kyk vgl 1 Mak $15: 1-2)$. Dit wil verder lyk of die begrip " $\varepsilon \theta v o c^{\prime} / \varepsilon \theta v \eta$ stelselmatig al hoe meer as ' $n$ (soms negatiewe) beskrywing van buitestanders (persone wat nie deel is van die eie groep nie) gebruik is, en $\gamma^{\prime}$ Vos as verwysing na die eie groep (Duling 2009:1-2). Vergelyk in laasgenoemde verband Paulus se uitspraak in Filippense 3:5, waar hy na homself as Israeliet verwys deur van $\gamma^{\prime} \varepsilon$ vos gebruik te maak.

4.Volgens Brown (2000:311) was Mead (in 1934) die eerste sosioloog wat oortuig was dat die sosiale identiteit van ' $n$ individu onder andere deur die identiteit bepaal word van die groep waartoe so ' $n$ individu behoort. Dit was egter Henri Tajfel $(1982,1986)$, 'n Poolse Jood, en later John Turner (1999) wat die sosialeidentiteitsteorie ('n onderafdeling van sosiologiese psigologie), ontwikkel het. Die sosiale-identiteitsteorie bestudeer die verhouding tussen die individu se Die sosiale-identiteitsteorie bestudeer die verhouding tussen die individu se selfverstaan en lidmaatskap van 'n groep, en toon dat'n individu se selfverstaan deur
die karaktereienskappe van die kollektief waartoe so ' $n$ individu behoort. Hierdie is die karaktereienskappe van die kollektief waartoe so ' $n$ individu behoort. Hierdie is
veral die geval in kollektiewe kulture soos die eerste-eeuse Mediterreense kultuur. Wanneer ' $n$ bepaalde kollektiewe groep bepaalde kenmerke begin toon, word 'n bepaalde selfverstaan en optrede stereotipies van die bepaalde groep, en word alle groepe sonder daardie kenmerke negatief gestereotipeer (kyk Esler 2002:186-187). Aangesien die onderhawige bydrae op die verhouding tussen groepe konsentree, en nie op die verhouding tussen individue wat deel is van 'n bepaalde groep nie, word daar hier op teorieë gefokus wat met kulturele etnisiteit (die verhouding tussen groepe) verband hou.

5.Feitlik alle omskrywings van etnisiteit toon dat die begrip verstaan kan word aan die hand van 'n bepaalde kultuur, en dié se verskille met ander kulture. Volgens Barth (1969:13-14) verwys etnisiteit na die sosiale organisering van kultuurverskille, terwyl De Vos $(1975: 9,16)$ ' $n$ etniese groep as 'n groep persone beskryf wat bepaalde tradisies met mekaar gemeen het, welke tradisies (bv geloof, taal en herkoms) van dié van ander groepe waarmee hulle in kontak is, verskil. Roosens (1994:84) meen ook dat etnisiteit met'n gedeelde herkoms en kulturele tradisies te make het. Nagel (1994:153) reken dat faktore soos taal, godsdiens, voorkoms, afkoms en streeksgebondenheid ' $n$ bepalende rol in die etnisiteit van ' $n$ bepaalde groep speel, terwyl Smith (1986:32) etniese groepe omskryf as 'named human populations with territory and a sense of solidarity' (kyk Cromhout 2007:82 vir'n vollediger beskrywing territory and a sense of solidarity' (kyk Cromhout
van sommige van bogenoemde omskrywings).

6.Sommige antropoloë reken dat die begrippe 'ras' en 'nasionaliteit' (nasie) meer geskik is om die verskille tussen verskillende groepe aan te toon. Die begrip 'ras' kan egter nie op die verskille tussen groepe in die antieke tyd (bv die tyd van Jesus en Paulus) van toepassing gemaak word nie, aangesien dit'n moderne begrip is wat eers in die 18de eeu na vore gekom het. Aanvanklik (in die Middeleeue) is daar geglo dat ' $n$ mens op grond van die drie seuns van Noag, drie rasse van mekaar kan onderskei, te wete die Semiete (Sem - Asiërs), die Hamiete (Gam - Afrikane) en Jafette (Jafe - Europeërs). In die 16de eeu is die term 'ras' gebruik om op afkoms te dui, en het dit stelselmatig sake soos fisieke eienskappe, kultuur en selfs nasionaliteit begin in vorit. In dien voro sapien (bv die vorm van (bv die vom veisoleerd gebiede sou ontstaan het. Die gevolg van hierdie teorie was 'n drievoudige rastipologie: die Mongoloïde, die Negroïde, en die Kaukasiers. In die Euro-Amerikaanse of Euro-Afrikaanse konteks het hierdie onderskeid die meerderwaardigheid van die Kaukasiese ras geïmpliseer. Hierdie teorie is in die onlangse verlede deur bioloë en antropoloë as pseudo-wetenskap afgemaak, aangesien dit geen wetenskaplike geloofwaardigheid het nie. Immigrante maak byvoorbeeld dikwels (veral in stede) bepaalde groeperinge uit op grond van taal, tuisland, gebruike, godsdiens en dieet
Die twee belangrikste teorieë ten opsigte van etnisiteit is primordialisme en konstruksionisme. Wat primordialisme betref, kan daar tussen kulturele- en sosiobiologiese primordialisme onderskei word. Eersgenoemde gaan van die standpunt uit dat individue wat tot ' $n$ bepaalde groep behoort ' $n$ natuurlike diepgewortelde gevoel van toegeneentheid teenoor ander lede van die groep ervaar - 'feelings that they believe are "natural", sometimes even "sacred" and have always been there' (Duling 2009:3). Hierdie gevoel kom veral na vore in tye van snelle maatskaplike verandering wanneer groepe normaalweg duidelike grense tussen 'ons' en 'hulle' stel. Shils (1957:130-145) en Geertz (1963:108-113) wys vyf eienskappe van groepe soos hierdie uit: familie, grondgebied (tuisland), taal, (kulturele) gebruike, en godsdiens. Hierdie vyf eienskappe word kultuurmatig geskep, vandaar die benaming "kulturele primordialisme". Sosiobiologiese primordialisme weer gaan van die vertrekpunt uit dat sekere geneigdhede in menslike optrede, soos altruïsme, aggressie en kriminaliteit, geneties oorgedra word (Van der Berghe 1987). Konstruksionisme, aan die ander kant, kan gesien word as 'n reaksie op kulturele primordialisme. Barth (1969:13-14), die vader van die konstruksionisme, is dit eens met die kulturele primordialisme dat aanduibare kulturele eienskappe, soos taal, kleredrag en dieet (wat hy 'cultural stuff' noem), belangrik is in die vorming van etnisiteit, maar nie as sodanig 'n bepaalde etnisiteit daarstel nie. Groepe gebruik hierdie kulturele eienskappe om hulleself te beskryf ten einde hulle as 'n groep van ander groepe in hulle onmiddellike sosiale omgewing te onderskei. Die sleutel tot die verstaan van die begrip van etnisiteit is dus nie 'cultural stuff' nie, maar die sosiale organisering van kulturele verskille. Etnisiteit is nie 'n natuurlike gegewe - inherent, vas en onveranderlik - nie, maar gekose, vloeibaar en veranderlik; iets wat deurlopend in nuwe kontekste in relasie tot ander groepe gekonstrueer word. Kortweg gaan etnisiteit dus oor sosiale grensvasstelling ('social boundary making' (Barth 1969:14). ${ }^{7}$

\section{Etnisiteit: 'n Sosiaalwetenskaplike model}

Hierbo is reeds na vyf eienskappe verwys wat verskillende etniese groepe volgens Shils (1957) en Geertz (1963) met die oog op 'social boundary making' inspan. Schermerhorn (1978:12) lys drie verdere eienskappe wat ook vir die doel aangewend word, te wete stamaffiliasie, nasionaliteit en fenotipiese eienskappe. ${ }^{8}$ Volgens Barclay (1996:404; 2007:99-112) word etnisiteit hoofsaaklik deur die kombinasie van twee faktore bepaal, te wete 'n gemeenskaplike voorgeslag, en (kulturele) gebruike, terwyl Cohen (1999:7) van oordeel is dat die godsdiens van 'n bepaalde groep voldoende is om tussen verskillende etniese groepe te

(voetnota 6 gaan voort...)

en nie verskille in fisieke voorkoms wat in bepaalde gebiede ontstaan het nie (Duling 2008:1; 2009:2). Dit beteken egter nie dat ras steeds as 'n maatskaplike, politieke en kulturele realiteit lewe nie. Ook die begrip 'nasionalisme' is moderne verskynsel. In die tyd van Jesus en Paulus was daar nie iets soos 'nasionalisme' nie, omdat nasies (lees volkslied, burgerskap, stemreg) soos ons dit vandag ken, nie bestaan het nie (Duling 2008:2). Kyk in hierdie verband ook die volgende opmerking van Gelardin (2009:3): 'Since words like "nation," "nationality," "nationalism," and particularly "race" seems to carry narrow and sometimes ideologically loaded modern concepts into ancient sources, "ethnicity" enjoys a good reputation among scholars today".

7.Instrumentalisme, sosiale psigologie en etnosimbolisme kan gesien word as aanpassings, uitbreidings of die verdere ontwikkeling van Barth se konstruksionisme. aanpassings, uitbreidings of die verdere ontwikkeling van Barth se konstruksionisme.
Die instrumentalisme reken dat etniese groepe hulle identiteit deurlopend konstrueer Die instrumentalisme reken dat etniese groepe hulle identiteit deurlopend konstrueer
ten einde sosiopolitieke eiebelang te bevorder (Varshney, in Duling 2009:3). Sosiale psigologie lê klem op herinneringe (mites) wat deur etniese groepe geskep word, psigologie lê klem op herinneringe (mites) wat deur etniese groepe geskep word,
wat hulle meerwaardig teenoor ander groepe stem, sowel as die negatiewe wat hulle meerwaardig teenoor ander groepe stem, sowel as die negatiewe
stereotipering van ander groepe om hulle as minderwaardig uit te beeld (Horowitz, stereotipering van ander groepe om hulle as minderwaardig uit te beeld (Horowitz,
in Duling 2009:4). Etnosimbolisme konsentreer op die geiddealiseerde verlede van die etniese groep wat deur vertellinge (mites) oor die uitverkorenheid van die groep sowel as die groep se vermoë om teen alle aanslae in te kon oorleef, tot uiting kom (Armstrong, in Duling 2009:4).

8.In hierdie verband is dit belangrik om daarop te let dat waarneembare fisieke verskille

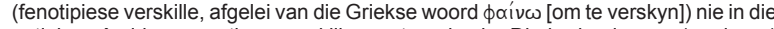
antieke wêreld as genetiese verskille verstaan is nie. Die hedendaagse (moderne) begrip van fenotipiese verskille (fenotipologie) as geneties oordraagbaar saam met bepaalde omgewingsfaktore, het nie in die antieke tyd bestaan nie. Etiopiërs (kyk bv Hand 8:27) se donker velkleur en donker krulhare is aan die uitwerking van die bv Hand $8: 27$ ) se donker velkleur en donker krulhare is aan die uitwerking van die son. Fenotipiese eienskappe is ook met bepaalde karaktertrekke verbind: Korintiërs (persone uit die streek van Korinte) is as gevolg van hulle klein ledemate, gesig en oë as bekrompe en kleingeestig beskou (Duling 2009:6). 
onderskei - hy verkies daarom die begrip 'etnoreligiositeit'. Mason (2007:457-512), op sy beurt weer, oordeel dat sosiale grensvasstelling aan die hand van (kulturele) gebruike, wette, tradisies en godsdienstige rituele as grensmerkers van etniese identiteit ('ethnic-identity boundary-markers') plaasvind (Mason 2007:469). Laastens voer Hutchinson en Smith (1996:6-7) aan dat etnisiteit deur ses eienskappe bepaal word, te wete ' $n$ naam wat op 'n bepaalde ethnos dui, 'n gemeenskaplike voorgeslag, 'n gedeelde geskiedenis (gedeelde herinneringe), ' $n$ gemeenskaplike kultuur, ' $n$ band met ' $n$ tuisland, en ' $n$ bewussyn van gemeenskaplike solidariteit (kyk ook Esler 2003a:43-44).

Deur die verskillende etnisiteitsteorieë met beskikbare antieke tekste te vergelyk wat die begrip van die etnisiteit van groepe weerspieël, is Duling $(2005 ; 2009)$ oortuig van oordeel dat die volgende nege eienskappe (soos dit deur die primordialisme aan die hand gedoen word) gebruik kan word om ' $n$ sosiaalwetenskaplike model daar te stel waarmee kulturele identiteit in die antieke tyd bestudeer kan word (kyk Duling 2005:127-128; 2009:4-7):

- Familie ('kinship'): In die Mediterreense wêreld was die familie waartoe iemand behoort het (straks) die belangrikste bepaler van kulturele identiteit (Malina 1986:152, 1989:131; Hanson \& Oakman 1998:7; Taylor 2002:577). ${ }^{9}$ In hierdie verband word daar dikwels in die Nuwe Testament met die uitdrukking 'A, seun van B (seun van C)' (die manlike bloedlyn) na persone verwys. Jakobus word byvoorbeeld as 'Jakobus, seun van Sebedeus' beskryf (vgl Mark 1:19, NAV), en Jesus as 'die seun van Josef' (Joh 1:45, NAV). Hierdie uitdrukking kom ook dikwels in die geslagsregisters van Jesus voor (Matt 1:1-17; Luk 3:23-38). ${ }^{10}$

- 'n Naam waaraan 'n etniese groep geken word: Die vrou wat Jesus in Matteus 15:22 ontmoet, word as ' $n$ Kanaäniet getipeer; die benaming van Jesus bo-aan sy kruis lui 'die koning van die Jode' (Matt 27:37, NAV); die Sanhedrin word in Markus 15:1 as die Joodse Raad beskryf; verskeie tekste verwys na die Jode as 'n groep (kyk bv Hand 6:9; Gal 3:28; Rom 2:17; 3:1); daar word dikwels na die Israeliete as 'n groep of volk verwys (kyk bv Rom 9:31;11:2); daar is verskeie verwysings na die Samaritane (kyk bv Matt 10:5; Luk 9:52); in Handelinge 22:26 word na Paulus as ' $n$ Romeinse burger verwys; en Filippus ontmoet 'n Etiopiër op die pad tussen Gasa en Jerusalem (Hand 8:27).11

- Land van herkoms (tuisland/geboorteland): Die Grieke, Romeine en Israeliete het dikwels groepe geëien deur na hulle land van herkoms te verwys (Hall 1997:47). Simon is van Sirene (Mark 15:21); die vrou wat Jesus by die put ontmoet is van Samaria (Joh 4:7); in Markus 7:24-31 word daar verwys na ' $n$ vrou uit Tirus en Sidon; en Israel was oortuig dat hulle in die 'beloofde land' geleef het (Gen 15:1821; Deut 6:10). Ook word daar dikwels na Jesus as 'Jesus van Nasaret' verwys (bv Matt 21:11; Mark 10:47; Luk 24:19; Joh 19:19; Hand 22:8). ${ }^{12}$

- 'n Gemeenskaplike voorgeslag (en/of mites daaroor): Die geslagsregisters in Matteus 1:1-17 en Lukas 3:23-38 is

9.Malina (1989:131; beklemtoning in die oorspronklike) beskryf die oorheersende waarde wat die familie in die Mediterreense wêreld gespeel het soos volg: 'In waarde wat die familie in die Mediterreense wêreld gespeel het soos volg: 'In ... the ... Mediterranean world ... the centrally located institution maintaining societal existence is kinship and its sets of interlocking rules. This results in the central value primary focus of personal loyalty and it holds supreme sway over individual life'.

10.Die belang van hierdie etniese merker kan veral in gevalle van negatiewe etikettering gesien word - Jesus sê byvoorbeeld aan die Jode wat nie in hom glo nie, dat God nie hulle Vader is nie, en dat hulle 'kinders van die duiwel' is (Joh $8: 42,44, \mathrm{NAV})$

11. Herodotos verwys na die Perse, Egiptenare en Libiërs as barbaroi, en die Romeine het die Grieke en Egiptenare as minderwaardig beskou (Duling 2009:6). Hieruit is dit duidelik dat name gebruik word om die een groep etnies meerwaardig ten opsigte van ander groepe uit te beeld.

12.Die antieke Joodse geskiedskrywer Josefus identifiseer sekere groepe deur onder andere na hulle land van herkoms te verwys (Duling 2009:6). 'n Persoon se land/ andere na hulle land van herkons te verwys (Duling 2009.6). 'h Persoon se land/ plek van herkoms is ook somyds gebruk om bepalde persone negatief te beoordeel: Om Jesus byvoorbeeld negatief uit te beeld word gese dat hy ' $\mathrm{n}$ Samaritaan (van Samaria) is (Joh 8:48), en Galileërs is afkomstig van 'Galilea waar die heidene woon' (Matt 4:15, NAV) hiervan voorbeelde, sowel as die uitdrukking 'kinders van Abraham' (kyk bv o a Joh 8:39, Rom 9:7; Gal 3:7). 'n Verdere voorbeeld van hierdie etnisiteitsmerker is die beskrywing van Israel in die Ou Testament as die nageslag van die voorvaders Abraham, Isak en Jakob (bv Eks 3:16; Deut 1:8; Jer 33:26). ${ }^{13}$

- (Kulturele) gebruike/tradisies: Die Jode het byvoorbeeld verskillende gebruike of tradisies gehandhaaf wat hulle van ander etniese groepe onderskei het. Voorbeelde hiervan is endogamiese huwelike, baarde by die mans, die oorgelewerde gebruike van die voorgeslagte (kyk bv Mark 7:5) en kleredrag (Mark 12:38). ${ }^{14}$

- Taal: In Handelinge 2:6-11 word daar na verskeie moedertale (dié van bv die Perse, Mediërs, Kretensers, Arabiere en Elamiete) verwys, wat op verskillende etniese groepe dui. Die Jode het Aramees gepraat, en hulle Skrifte (die Tanak) is oorwegend in Hebreeus neergepen. Paulus wys byvoorbeeld in Filippense 3:5 daarop dat hy ' $n$ Hebreër is (en dus ook Hebreeus magtig was) uit die stam van Benjamin, en dus ' $n$ Israeliet (Jood) is. ${ }^{15}$

- 'n Gedeelde geskiedenis (gedeelde herinneringe): Die Jode het hulle gereeld herinner aan hulle bevryding as slawe en die uittog uit Egipte (Eks 13:3; 16;20:2), die verbond wat God met hulle gesluit het en die land wat God aan hulle beloof het (Gen 12:1-3), en God se versorging op hulle tog deur die woestyn (kyk bv Joh 6:49). Herinneringe aan hierdie gebeure het gedien om hulle etniese identiteit te versterk en behoue te laat bly. ${ }^{16}$

- Fenotipiese eienskappe: In die antieke wêreld het waarneembare fisieke verskille ook as 'n etniese merker gedien (kyk egter weer voetnoot 8). Die Etiopiër wat na Jerusalem toe gekom het om te kom aanbid (Hand 8:27) se oënskynlik waarneembare donker velkleur en donker krulhare het Filippus laat besef dat hy van 'n ander etnisiteit was.

- Godsdiens: In die Mediterreense wêreld was godsdiens in die familiale en politieke instelling (kyk Malina 1986:86; 2001:36). 'Religion as a sphere apart, that is, separated from other cultural, social, and ethnic discourses, is not conceivable in antiquity' (Gelardini 2009:5). Die Jode het verskeie godsdienstige gebruike gehandhaaf wat hulle van ander etniese groepe onderskei het. Die volgende dien as voorbeelde: besnydenis (kyk bv Luk 2:21; Eks 13:1); rein (kosjer) kos en reinheidsmaatreëls (kyk bv Mark 7:1, 15); Sabbatswette (kyk bv Mark 2:24; Joh 5:10; 9:16) en die wet van Moses (Jos 8:32; Matt 1:19; Luk 2:22); die praktyk van vas (bv Mark 2:18); die hou van feeste (bv die Paasfees [Joh 2:13] en die Loofhuttefees [Joh 7:2]) en godsdienstige kleredrag (gebedsbande om die voorkop en tossels aan klere; kyk bv Matt 23:5). ${ }^{17}$ Sowel die Romeine as die Jode het geglo dat hulle God se 'uitverkore volk' was. Die Romeine het daarop aanspraak gemaak dat hulle deur die gode, veral Jupiter, uitgekies is om oor ' $n$ ryk te regeer 'wat nooit ' $n$ einde sou hê nie' (Virgilius, Aeneas 1.278-279; Seneca, Duties 2.26-27; kyk ook Carter 2006:7). Die Jode het weer húlle oortuiging

13. Volgens Herodotos het etniese groepe soos die Egiptenare, die Romeine en Grieke dikwels hulle oorsprong na die gode en helde van hulle voorgeslag teruggevoer 'Hall 1997:41-43). ' $n$ Soortgelyke voorbeeld is in Eksodus 3:16 in die uitdrukking 'die God van julle voorvaders, die God van Abraham, Isak en Jakob' (NAV) te vinde. wat dié rykes se sosiale status kon verhoog (Hood, in Duling 2009:5).

14.Die Griekse digter Anakreon (6de eeu vC) meld byvoorbeeld dat die Doeriane aan hulle kenmerkende kleredrag uitgeken kon word (Hall 1997:38).

15.Die Grieke het ander etniese groepe op grond van hulle taal as brabbelaars/ babbelaars beskou (barbaroi; Geary, in Duling 2009:6), en die Egiptenare het ander etniese groepe wat nie Egipties kon praat nie, as 'andertaliges' bestempel - maar net twee voorbeelde wat daarop dui dat taal in die antieke wêreld as 'n etnisiteitsmerker gedien het.

16.Wat die herinneringe en geskiedenis van die Grieke en Romeine betref, maak Duling (2009:6) die volgende raak opmerking: 'The Greeks had Homer's Iliad; Romans had accounts of the founding of Rome (Plutarch, Lives of Romulus). Greek and Latin historians wrote to reinforce ethnic identity'.

17.Soos die Jode, het die Romeine ook godsdienstige en ander gebruike gehandhaaf wat hulle van ander etniese groepe onderskei het, byvoorbeeld mites oor gode, die verering van voorvaders, Vestaalse maagde, feeste, optogte en speles (Neils, in Duling 2009:6). 
dat hulle God se uitverkore volk was (vgl Ps 78:61; Jes 43:20) op hulle bevryding van slawerny in Egipte en die gawe van die beloofde land gegrond (Herzog 2005:127)

In die toepassing van bogenoemde sosiaalwetenskaplike model wys Duling (2009:5) daarop dat ' $n$ bepaalde etniese groep nie oor al nege bogenoemde eienskappe hoef te beskik om as ' $n$ afsonderlike etniese groep beskou te word nie. In die meeste gevalle is familie, gedeelde geskiedenis (herinneringe) en ' $n$ land van herkoms universeel aan verskillende etniese groepe. Voorts moet onthou word dat ' $n$ bepaalde etniese groep se identiteit vloeibaar is, afhangende van byvoorbeeld veranderende omstandighede en nuwe kontekste (konstruksionisme). Dit is ook moontlik dat ' $n$ persoon meer as een etniese identiteit kan hê: Die Jood Saulus (Hand 8:1,3) of Saul (Hand 9:1) van Tarsus was ook Paulus, 'n Romeinse burger van geboorte (Hand 22:28). Ten slotte bied Duling verskeie antieke tekste aan wat daarop dui dat die nege bogenoemde etniese eienskappe inderdaad gebruik is om tussen verskillende groepe se etnisiteit te onderskei..$^{18}$

\section{JOODSE ETNISITEIT: 'N EKSKLUSIEWE GOD}

'n Volledige beskrywing van wat Joodse etnisiteit in die eerste eeu in Palestina behels het, is nie hier moontlik nie. ${ }^{19}$ ' $n$ Bondige beskrywing van die essensie van Joodse etnisiteit in eerste-eeuse Palestina is egter voldoende vir die doel van die onderhawige bydrae.

Hierbo is reeds na sekere aspekte verwys wat Joodse etnisiteit bepaal het. Wat familie betref, was die familie waartoe iemand behoort het straks een van die belangrikste bepalers van Joodse etnisiteit/identiteit, aangesien die familiale instelling die dominante instelling in die eerste-eeuse Mediterreense wêreld was. Manlike bloedlyne was belangrik in die bepaling van etnisiteit en status, wat onder andere op die paternalistiese en hiërargiese aspekte dui wat kenmerkend van die Joodse ethnos was. ' $n$ Tweede etnisiteitsmerker was die benaming van hierdie etniese groep, Jood (Judeër; 'Israeliet[e]' wat in Judea gewoon het), dit wil sê, persoon of persone wat godsdienstig en kultureel-etnies aan die Judeanisme (etniese bande met Judea, en verbind met die tempel in Judea [Jerusalem]) gekoppel kan word. ${ }^{20}$ Wat land van herkoms betref, het die Jode in Palestina gewoon, wat hulle as die 'beloofde land' beskou het. In die vierde plek het die Jode ' $n$ gemeenskaplike voorgeslag gehad - hulle was die nageslag van die voorvaders Abraham, Isak en Jakob, en het hulleself as kinders van Abraham beskou op

18.Duling (2009:7) lys die volgende drie tekste wat as grondslag vir sy voorgestelde model dien (etnisiteitsmerkers tussen hakies en gekursiveer telkens eie byvoegings):

Daar is verskeie belangrike redes waarom ons as Grieke (naam) nie na die Perse (naam) moet oorloop nie, al wil ons miskien: in die eerste plek hulle verbranding en verwoesting van die versierings (godsdienstige gebruke) en tempels van ons gode (godsdiens) ... verder die verwantskap/familieskap van die Grieke (voorgeslag) in terme van bloed en taal (taal) ... die heiligdomme van ons gode (godsdiens) . die offers wat ons in gemeen het (godsdienstige tradisies en gebruike) ... die ooreenkoms in ons wyse van lewe (kulturele gebruike) ... alles dinge wat ons as Ateners (naam) nie kan versaak nie (Herodotos, Histories 8.144.2 [circa $440 \mathrm{vC}$ ]; eie parafrase).

Die ethnos (etnisiteit) van die Armeniërs (naam), die Siriërs (naam) en die Arabiere (naam) wys op hulle verwantskap aan mekaar (voorgeslag), nie alleen in taal nie (taal), maar ook in hulle wyse van lewe (kulturele gebruike), hulle liggaamlike ooreenkomste (fenotipiese eienskappe), en veral die feit dat hulle as bure saamleef (land) ... (Strabo, Geography 1.2.34 [circa 17-23 nC]; eie parafrase).

Hulle is almal die nageslag (voorgeslag) van Sem (naam), met hulle eie stamme (familie) en tale (taal), in hulle eie lande (land) en onder hulle eie nasies ( $d$ ws, etnisiteit; Gen 10:31, NAV). (Die nie-priesterlike oergeskiedenis, soos dit in Genesis $1-11$ beskryf word, is waarskynlik tussen 500 en $400 \mathrm{vC}$ skriftelik gefikseer).

19.Vir 'n volledige beskrywing van die aspekte wat Joodse etnisiteit in die eerste eeu in Palestina bepaal het, kyk Cromhout (2007:117-230). Een van die waardes van Cromhout se beskrywing is sy gebruik van nie-kanonieke bronne ter stawing van sy beskrywing van Joodse etnisiteit in die eerste eeu in Palestina. In die onderhawige bydrae word doelbewus nie van nie-kanonieke bronne gebruik gemaak nie ter wille van die beoogde teikengroep van die bydrae. Cromhout (2007:67-115) bied ook 'n omvattende sosiokulturele model waarmee Joodse etnisiteit in die eerste eev in Palestina bestudeer kan word - in model waarvan daar gerus kennis geneem kan word.

20.In verskeie tekste in die Nuwe Testament word daar na die Jode as 'n e!qnov verwys, soms deur hulle wat deel is van die Joodse ethnos (Luk 23:2; Joh 11:19, 50-52), en soms deur persone wat tot'n ander ethnos behoort (Luk 5:7; Joh 18:35). grond van die verbond wat God met Abraham (en sy nageslag) gesluit het. ${ }^{21}$ Die Jode het voorts verskeie (kulturele) gebruike/ tradisies gehandhaaf wat hulle van ander etniese groepe onderskei het (bv endogamiese huwelike, baarde by mans, die oorgelewerde gebruike van die voorgeslagte, en kleredrag). Die taal van die Jode was Aramees ${ }^{22}$ (waarvan 'n aantal transliterasies in die Griekse Nuwe Testament voorkom), ${ }^{23}$ en die taal van die Tora was Hebreeus. Wat gedeelde geskiedenis (gedeelde herinneringe) as etnisiteitsmerker betref, het die Jode hulle gereeld herinner aan hulle bevryding as slawe en die uittog uit Egipte, die verbond wat God met hulle gesluit het, die land wat God aan hulle beloof het, en die wet wat God aan hulle gegee het - hulle was dus God se uitverkore volk. Die feit dat hulle God se uitverkore volk was met wie God 'n verbond gesluit het (wat die gee van die wet insluit), het aan die Jodedom n kollektiewe identiteit sowel as 'n bewussyn verleen dat hulle anders as ander etniese groepe was (Cromhout 2007:119). Die Jodedom het ook verskeie godsdienstige gebruike gehandhaaf wat hulle duidelik van ander etniese groepe onderskei het, waarvan die besnydenis seker een van die belangrikste onderskeidende kenmerke was. Ander godsdienstige gebruike het ingesluit kosjer kos, reinheidsmaatreëls, die bring van offers, die hou van die Sabbat (die Sabbatswette), die praktyk van vas, die hou van feeste, en godsdienstige kleredrag (gebedsbande om die voorkop en tossels aan klere). Ten slotte het die tempel as dié godsdienstige simbool gedien, wat Joodse etnisiteit die sigbaarste tot uiting laat kom het. ${ }^{24}$

Aangesien godsdiens in die eerste-eeuse Mediterreense wêreld ingebed was in die familiale- en politieke (en ekonomiese) instellings het die godsdiens van die Jodedom 'n baie groter rol in die bepaling van hulle etnisiteit gespeel as net die paar eienskappe wat hierbo onder godsdiens genoem word. Godsdiens was so integraal deel van Joodse etnisiteit dat die Jodedom selfs as ' $\mathrm{n}$ etnoreligieuse ethnos beskryf sou kon word (kyk Cohen 1999:109). Die Jodedom van die Tweede Tempeltydperk het God in terme van sy heiligheid verstaan (kyk bv Lev 19:2, NAV: 'Wees heilig, want ek die Here julle God is heilig'25). God se heiligheid was sigbaar in sy vermoë om te seën of te oordeel (Douglas 1966:48-57). God se seën het die skep van orde behels, waarvan die skepping as God se grootste seëning ooit beskou is. Deur sy skepping het God orde geskep deur dag en nag van mekaar te skei, die week in werksdae en 'n rusdag in te deel, voëls, diere en visse is in hulle 'opregte/egte' vorme geskep (nie basters nie, bv 'n muil), land en see is van mekaar geskei, aan elke lewende wese is ' $n$ bepaalde plek toegeken (bv visse in die water en voëls in die lug), en die mens is aangestel om oor God se skepping te heers (hiërargie). God se skepping het dus ' $n$ bepaalde orde daargestel wat tyd, plek, persone en status betref. In die woorde van Neyrey (1991:277): 'a place for everything and everything in its place'. God se heiligheid was orde, en om heilig te wees soos God heilig is (kyk weer Lev 19:2) het beteken dat God se orde in ' $n$ samelewing gestalte moes kry wat God se heilige ordening van sy skepping weerspieël het. ${ }^{26}$

21. Kyk in hierdie verband die volgende opmerking van Cromhout (2007:121): 'To be a child of Abraham is to have an elevated status, that is, to have the glorious status of being a Judean (Jood - EvE)'.

22. As gevolg van Hellenisering was daar ook baie Jode wat Grieks kon praat en selfs Grieks as 'moedertaal' gehad het (vgl o a Drane 1977:119-120).

23.Kyk onder andere Markus 5:41; 7:34; 11:9; 14:36; Matteus 5:10, 22; 6:24; 27:6, 46 en Johannes 8:29; $20: 16$.

24.Ingevolge Duling se sosiaalwetenskaplike model oor etnisiteit is daar dus ag tipiese eienskappe (wat fenotipiese kenmerke uitsluit) wat op Joodse etnisiteit dui.

25.Kyk ook Eksodus 15:11; Levitikus 10:3, 11:43-45; 20:7-8, 26; 21:8; Psalm 99:3, 5, 9: 111:9; Jesaja 6:6, 65:5 en Amos 4:2.

26.Kyk in hierdie verband die volgende opmerking van Neyrey (1991:273): 'By imposing order, people are attempting to define themselves. Chaos, the complete absence of order, was a terrifying concept, for it implies that there are no patterns, no identifications, no rules, no structures .... People, then, seek to find order ... to define themselves .... By erecting imaginary and/or real lines, people define "my" or "ours" in relation to what is "yours" and "theirs", which is the function of city walls, or "ours" in relation to what is "yours 
In die Jodedom het die tempel (as die axis mundi), ${ }^{27}$ die sentrale godsdienstige simbool van die Joodse ethnos, as die beliggaming van God se heiligheid gedien (Neusner 1979:103-127; Neyrey 1991:277). Om God se heiligheid te repliseer is bepaalde heiligheidsmaatreëls in plek gestel wat bepaal het watter diere geoffer mag word (geen basters of diere met gebreke nie), wie die offers mag bring (slegs heilige priesters van ' $n$ bepaalde bloedlyn), wie aan die offers mag deelneem (slegs Israeliete sonder gebreke), waar die offers gebring mag word (slegs in die tempel), sowel as watter offers op watter tye gebring mag word (bv feeste). Op hierdie wyse is daar uiting gegee aan die opdrag om heilig te wees soos God heilig is, en het die tempel as die sentrale en oorheersende godsdienstige, politieke en ekonomiese simbool van die Jodedom gedien. ${ }^{28}$

Hierdie begrip van God se heiligheid, soos dit in die tempelmaatreëls vervat is, het in wese bepaal wie by God (in die tempel) welkom was, en wie nie. Slegs Israeliete (sonder gebreke) kon in die tempel kom om offers te bring; vroue kon nie in die tempel kom nie (net in die voorhof van die vroue); kinders was uitgesluit, en so ook diegene wat as sosiaal onrein gereken was. Persone met gebreke wat nie heilig/heel was soos God nie (die sg 'sondaars,' bv blindes, verlamdes, hermafrodiete, melaatses, ${ }^{29}$ en mans met beskadigde geslagsdele) was ook nie welkom in die tempel nie, asook diegene wat as permanent onrein beskou is (bv tollenaars ${ }^{30}$ en prostitute). Hierdie 'sondaars' is beskou as persone wat nie by God teenwoordig kon wees nie (want God is heilig en heel), en was daarom nie welkom in die tempel nie.

Kortom het dit daarop neergekom dat ' $n$ bepaalde begrip van God (wat sy heiligheid betref) diskriminasie ten opsigte van sekere persone in die hand gewerk het. God was net in die tempel teenwoordig. Hy was heilig en heel - 'n eksklusiewe God. Net hulle wat heilig en heel was, het by God gepas. Net Israeliete (Jode) was welkom, en dan ook net die 'heiliges' of 'reines' onder hulle - 'n uitsluiting van persone op grond van 'goddelike sanksie'. God was immers heilig en heel, en slegs hulle wat ook 'heilig' en 'heel' was, kon in God se teenwoordigheid kom.

Ten slotte kan daar na ' $\mathrm{n}$ aantal kulturele waardes verwys word wat, hoewel dit universeel vir die Mediterreense wêreld gegeld het, ook aan die Joodse ethnos uitdrukking gegee het. Die dominante kulturele waarde (spilas) van die Joodse ethnos was eer en skaamte. ${ }^{31}$ Persone in die eerste-eeuse Mediterreense wêreld was altyd ingebed in die paternale familie $(\mathrm{d} \mathrm{w} \mathrm{s}$, in die eer van die hoof van die familie, die pater familias; kyk Malina \& Rohrbaugh 1992:377). Die Joodse ethnos was dus oorwegend

27.Axis mundi is ' $\mathrm{n}$ term wat na die middelpunt van die aarde verwys - die plek waar die goddelike en die menslike mekaar ontmoet, oftewel die plek waar die goddelike op die aarde teenwoordig is.

28.Gelardini (2009:3) som bogenoemde raak op deur die Jodedom as 'n 'specific religious system' te beskryf: '[B]elonging to the Jews, the Jewish people or nation or an ethnic collective, and belonging to Judaism as a cultural identity ... is mostly understood as a specific religious system.'

29.Melaatses is as onrein gereken, aangesien hulle nie grense gerespekteer het nie. Die vel was 'n grens vir vloeistof in die liggaam. Melaatse persone se liggaamsvog was egter buite die liggaam, en dus is hulle as ' $n$ simbool van chaos (wanorde) beskou. Om hierdie rede is hulle as onrein en as deel van die sosiaal-veragtes bestempel.

30.Die negatiewe gevoel oor tollenaars in die Nuwe Testament lê op verskeie vlakke: 1) Die Jode het geoordeel dat tollenaars verraaiers was, aangesien hulle die geld van die plaaslike bevolking aan Rome oorhandig het; 2) tollenaars was gedurig in aanraking met onrein items en onrein mense; 3 ) tollenaars is as rowers beskou, omdat hulle tol geëis het wat hulle nie toekom nie (daarom mag hulle ook nie [saam met herders en openbare amptenare] in 'n hof getuig het nie); en 4) tollenaars het geld hanteer met ' $n$ afbeelding van die kop van die keiser daarop. Dit is as ' $n$ oortreding van die eerste gebod (die keiser is as ' $n$ god vereer) en die tweede gebod (jy mag geen gesnede beeld of afbeelding maak nie) beskou. Tollenaars is dus as permanent onrein beskou.

31.Malina (1981:27-29) beskryf eer en skaamte as kernwaarde van die eerste-eeuse Mediterreense wêreld soos volg: 'Honor might be described as socially proper attitudes and behavior in the area where the three lines of power, sexual status, and religion intar. (the is, one's claim to worth) plus that person's value in the eyes of his own socia group.... Honor is a claim to worth and the social acknowledgement of that worth.... society, he or she expects others in the group to acknowledge the fact, and what results is a grant of honor, a grant of reputation. manlik. Die eerste-eeuse Mediterreense wêreld het nie iets soos 'n 'individu' geken nie, en persoonlikheid was 'ander-gerig' ('dyadic'). ${ }^{32}$ Elke individu was ingebed in die groep (die familie en ethnos) waartoe hy of sy behoort. Persone in die eerste-eeuse Mediterreense wêreld was dus sterk groepspersone, met ' $n$ psigologiese verwysingsraamwerk wat altyd hoofsaaklik op die groep gerig was. 'Ek' het altyd ' $\mathrm{n}$ 'ons' ingesluit; 'ek' was altyd deel van 'n groter 'ons' (Malina \& Neyrey 1991a:74). Diadiese persoonlikheid was in beginsel ook agonisties, dit wil sê persone wat nie deel van die eie groep was nie, is altyd negatief beoordeel: Persone met ' $n$ ander etnisiteit is by verstek as vyande gereken, en persone met dieselfde etnisiteit maar nie deel van byvoorbeeld die dorp nie (vreemdelinge), is as potensiële vyande beskou (Malina \& Neyrey 1991b:32). ${ }^{33}$ Ten slotte kan daar kortliks na tafelgemeenskap in die Joodse ethnos verwys word. Omdat kultiese reinheid so belangrik is, het soort net saam met soort geëet ( $\mathrm{d}$ w s, rein saam met rein).

In die Joodse ethnos was grense dus belangrik. Iemand was of deel van die ingroep, of nie. Sommige lede van die ingroep, die 'onreines' of sosiaal-veragtes, was egter nie aanvaarbaar vir ander in die ingroep nie. Kultiese reinheid was die norm, en dit het bepaal of iemand in God se teenwoordigheid kon kom (hoewel natuurlik slegs as jy ' $\mathrm{n}$ man was). Iemand buite die Joodse ethnos kon wel deel van die Jodedom word, maar moes daarvoor 'Jood' word, gewoonlik deur middel van die besnydenis. Die Joodse ethnos was duidelik eksklusief - God was immers 'n eksklusiewe God.

\section{JESUS: GOD IS INKLUSIEF}

Anders as die tempel en die Jodedom van sy tyd, het Jesus God aan die hand van God se medelye verstaan. Hierdie Godsbegrip van Jesus word in Lukas 6:48 uitgedruk, waar Hy Levitikus 19:2 se formulering, 'Wees heilig, want ek die Here julle God is heilig' (NAV), herformuleer as 'Wees barmhartig (o'ikTі ṕpoves) soosjulle Vader barmhartig (o’ıтा $\rho \omega \omega v$ ) is' (NAV). ${ }^{34}$ Jesus vervang dus die tempel se begrip van God aan die hand God se heiligheid, met 'n begrip van God aan die hand van God se medelye/deernis/ barmhartigheid. Anders gestel, vervang Jesus 'n eksklusiewe God met 'n inklusiewe God (kyk o a Cupitt 2001:58).

Jesus se verstaan van God aan die hand van God se medelye blyk eerstens uit sy omgang met die reinheidsmaatreëls van die tempel. Wat plek betref, het Jesus dikwels buite die 'heilige' grense van Israel beweeg (bv Samaria [Luk 9:51-56]; Dekapolis [Mark 7:31]; Sesarea-Filippi [Mark 8:27]; Gerasa [Mark 5:1; Luk 8:26]), en in die 'heilige land' self met persone van ander ethnos omgegaan (Griekse vrou uit Siro-Fenisië [Mark 7:26]; ‘n Kanaänitiese vrou uit die gebied van Tirus en Sidon [Matt 15:2122]; die besetene van Gerasa [Mark 5:2]; ' $n$ Romeinse offisier [Luk 7:1-10]). In hierdie verband het Jesus selfs die geloof van 'n Romeinse offisier (Matt 8:10) ${ }^{35}$ en ' $n$ Kanaänitiese vrou (Matt 15:28) geprys, en ' $n$ Samaritaan as ' $n$ voorbeeld van naasteliefde aan tempelpersoneel voorgehou (Luk 10:30-35).

Ook het Jesus voortdurend met persone omgegaan wat volgens die reinheidsmaatreëls van die tempel as sosiaal-veragtes (onrein [nie heilig, nie-heel]) gereken is: kreupeles/verlamdes/

32.'Mediterraneans are what anthropologists call "dyadic"; that is, they are otherorientated people who depend on others to provide them with a sense of who they are' (Malina \& Rohrbaugh 1992:113; eie beklemtoning).

33.Die agonistiese aard van die eerste-eeuse Mediterreense wêreld, en dus ook die Joodse ethnos, word deur die volgende veelseggende Mediterreense spreekwoord uitgedruk: 'Me against my brother, me and my brother against our cousin, me, my brother and my cousin against our enemies' (kyk Malina 2001:46).

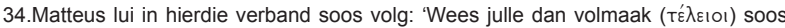

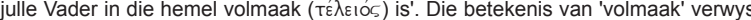
hier heel waarskynlik na verskeie uitsprake van Jesus vroeër in die bergrede (Matt 5:3-48) oor wat konsekwente optrede beteken, veral dié in Matteus 5:43-47, waar .3-48) oor wat konsekwenté optrede beteken, veral dié in Matteus 5:43-47, waar Jesus sẽ dat jy jou naaste én jou vyande moet liefhê. God is 'volmaak' omdat Hy die son oor slegtes en goeies laat opkom, en dit oor slegtes en goeies laat reën. (konsekwent) lief te hê.

35.'Ek het nog by niemand in Israel so 'n groot geloof teëgekom nie' (NAV). 
gebreklikes (Luk 5:17-26; Mark 3:1-5; 7:31-35), blindes (Luk 7:21; Mark 8:22-25; 10:46-52), siekes (Luk 4:38-40), duiwelbesetenes (Luk 4:31-27; 8:26-39; Mark 1:32-34; 9:17), melaatses (Mark 1:40-42) en die sogenaamde 'sondaars' (tollenaars [Mark 2:1315]; prostitute [Matt 21:31-32; Luk 7:37-50]; kyk o a Armstrong 2001:26). Wat laasgenoemde betref, het Jesus by geleentheid aan die priesterhoofde en familiehoofde gesê dat tollenaars en prostitute, eerder as hulle, in die koninkryk van God sal ingaan (Matt 21:23,31). Jesus het ook gereeld met vroue, wat volgens die Joodse ethnos as besittings ${ }^{36}$ sonder eer, en van mindere status ${ }^{37}$ gereken is, omgegaan (kyk bv Matt 26:10; Mark 5:25-34; 7:25; 14:3; Luk 13:11; Joh 4:7; 8:3-11) en hulle by Hom en sy volgelinge verwelkom (Luk 8:3; 10:38; kyk o a Bailey 2008:194-195). Vroue is ook dikwels karakters in die gelykenisse wat Hy vertel het (Matt 13:13; Luk 15:18)..$^{38}$ Dit is interessant dat die geslagsregister van Jesus in Matteus 1:1-17 ook name van vroue met óf (bedenklike) reputasies (Tamar en Ragab) óf nie-Jode (Rut, 'n Moabiet) bevat. Dieselfde kan van Jesus se ingesteldheid teenoor kinders gesê word (Mark 9:33-37; 10:13-16) ${ }^{39}$ Hy het selfs aan dooies (persone wat as die onreinste van almal beskou is) geraak (Luk 7:11-17; $8: 49-56)$ en van onrein spoeg gebruik gemaak om 'n doofstom man te genees (Mark 7:33).

Jesus het ook nie die tempel se ordening van tyd gehandhaaf nie deur die Sabbatswette te ignoreer (Mark 2:23), en selfs 'n man met ' $n$ gebreklike hand op die Sabbat te genees (Mark 3:1-5). Jesus het ook nie die dae waarop gevas moes word, nagekom nie (Mark 2:18). Dieselfde geld vir die reinheidsmaatreëls oor kos (kyk bv Mark 6:35-44; 7:1). Jesus het dikwels saam met tollenaars en sondaars geëet (Matt 9:10-11; 11:19; kyk o a Patterson 2004:41). Dit is dan ook in hierdie verband (die eet van rein kos saam met 'reines') dat Jesus die oorgelewerde gebruike van die voorgeslagte kritiseer (Mark 7:8).

Jesus het voorts die tempel (dié sentrale simbool van die Joodse ethnos) fel gekritiseer. Die evangelies bevat verskeie negatiewe uitsprake van Jesus ten opsigte van die tempel, die tempelpersoneel en tempelsisteem kom in die evangelies voor (vgl bv Matt 23:16-22; Luk 13:34-35; 19:41-44; 21:20-24). Deur mense hulle sondes te vergewe (kyk o a Mark 2:9) het Jesus in wese die tempel- en offersisteem as uitgedien verklaar. Wanneer Jesus later in Jerusalem sy aksie in die tempel uitvoer, verklaar hy ook dat die tempel ' $n$ rowersnes geword het, in plaas daarvan om 'n huis van gebed vir al die nasies ( te wees. Die tempel kon dus, volgens Jesus, nie eksklusief die Joodse ethnos s'n wees nie. ${ }^{40}$ Jesus het ook nie net Jode as kinders van Abraham (Isak en Jakob) beskou nie. Hy het geoordeel dat hulle wat nie die wil van God doen nie (ook Jode), nie kinders van Abraham is nie (Matt 3:9; Luk 13:28; Joh 8:33, 37, 39-40). Daarteenoor het Hy weer persone wat die tempelsisteem nie as kinders van Abraham erken het nie (bv die gebreklike [onrein] vrou [Luk 13:16]; hulle van die ooste, die weste, die noorde en die suide [nie-Jode; Matt 8:11; Luk 13:29]; Levi, die [onrein] tollenaar [Luk 19:9]) wel as kinders van Abraham beskou.

Jesus het ook van die dominante kulturele waardes van die Jodedom van sy tyd bevraagteken. Wat eer as dominante waarde betref, was Jesus in die oë van die Joodse godsdienstige leiers ' $n$ skaamtelose persoon, omdat hy met onrein mense omgegaan het en nie by die reinheidsmaatreëls van die tempel gehou het nie.

\section{Kyk byvoorbeeld Matteus 18:25}

37.Kyk byvoorbeeld Markus 5:35

38. In Lukas 15:3-31 vertel Jesus 'n drietal gelykenisse waarin twee mans en 'n vrou dieselfde rol speel (om terug te kry wat verlore was) - Jesus beskou dus die twe geslagte as gelyk in status

39.In die patriargale familie het kinders feitlik geen status gehad nie. Minderjariges se status was soos die van slawe. Weeskinders was die simbool van absolute weerloosheid, en om ' $n$ volwasse persoon ' $n$ kind te noem is as uiters vernederend weerloosheid, en om ' $\mathrm{n}$ volwasse persoon $\mathrm{n}$ kind te noem is as uiters vern

40.In hierdie verband kom daar verskeie ander tekste in die evangelies voor waarin Jesus die teenwoordigheid van God aan 'n groter groep as net die Joodse ethno beskikbaar stel (kyk Matt 18:8, 21; 21:43; 25:32; 28:19; Luk 2:32; 24:27).
Vir Jesus was dit egter belangriker om medelye met ander te hê as om in die tempelstelsel se oë ' $n$ eerbare persoon te wees. Ten slotte was Hy ook baie krities oor die familiale instelling van sy tyd. ${ }^{41}$

Uit bogenoemde is dit duidelik dat Jesus feitlik elke aspek wat Joodse ethnos uitgemaak het, bevraagteken het. Ingevolge Duling se model hierbo (kyk weer § 3.2) het Jesus minstens sewe van die eienskappe wat die Joodse ethnos bepaal het, nie as bepalend geag om by God teenwoordig te kan wees nie, naamlik familie, benaming, land van herkoms, 'n gemeenskaplike voorgeslag, (kulturele) gebruike/tradisies, gedeelde geskiedenis/herinneringe, en godsdienstige gebruike. Dit was veral die tempel - en die grense wat die tempel daargestel het om sekere persone uit te sluit - wat onder fel kritiek deurgeloop het. God was nie 'n God van heiligheid nie, maar 'n God van medelye. Hierdie medelye was beskikbaar aan alle mense - ook aan hulle wat wel deel was van die Joodse ethnos, maar as onrein beskou is, sowel as hulle wat nie deel was van die Joodse ethnos nie. Die skrifgeleerdes en die priesterhoofde het Jesus nie verniet as ' $n$ 'opruier van die volk' beskou nie (Luk 23:14, NAV).

\section{PAULUS EN ETNISITEIT}

\section{Etniese konflik in Filippense, 2 Korintiërs en} Galasiërs

In Paulus se briewe aan die Filippense, 2 Korintiërs en Galasiërs is daar telkens sprake van konflik tussen twee groepe heel waarskynlik tussen wetsvrye nie-Joodse gelowiges en wetsgehoorsame Joodse gelowiges wat wou vashou aan die 'werke van die wet' (die besnydenis, reinheidswette oor die eet van voedsel, en die hou van die Sabbat). Die konflik in Filippense gaan duidelik daaroor dat die wetsgehoorsame Joodse gelowiges ('die mense wat kwaad stig'; Fil 3:2, NAV) daarop aangedring het dat die nie-Jode (proseliete) hulleself moes besny (Fil 3:2). Die wetsgehoorsame Joodse gelowiges het geoordeel dat gelowiges slegs kinders van God kon wees indien hulle besny word ('op uiterlike dinge vertrou', Fil 3:3: NAV). Kortom, om kind van God te wees moes iemand eers ' $n$ 'Jood' word. In Galasiërs handel die konflik in die gemeente in die eerste plek ook oor die besnydenis: Die wetsgehoorsame Jode - 'mense wat die evangelie van Christus probeer verdraai' (Gal 1:7), 'Jakobus se mense ... die voorstanders van die besnydenis' (Gal 2:12; NAV) - was van mening dat nie-Joodse gelowiges die besnydenis moes ontvang (Gal 5:11). Hulle het dus gemeen dat die wet van Moses onderhou moes word om van sonde vrygespreek te word (Gal 2:16). In Galasiërs gaan die konflik egter ook oor ' $n$ verdere saak, naamlik reinheidswette oor die eet van voedsel. Van die Jode wou nie saam met nie-Jode eet nie (Gal 2:12-13). Wat 2 Korintiërs betref, is daar geen inligting wat ons in staat stel om die aard van die konflik in die gemeente bepaal nie. Wat wel afgelei kan word is dat daar 'n groep 'apostels' in die gemeente was wat Paulus se apostelskap bevraagteken het. Hulle word as 'Hebreërs' beskryf - 'Israeliete' wat van Abraham afstam (2 Kor 11:22). Hieruit kan minstens afgelei word dat hulle Jode was. Kortom was die konflik in Filippense, 2 Korintiërs en Galasiërs heel waarskynlik etnies van aard, aangesien die besnydenis, reinheidswette oor die eet van voedsel, en die hou van die Sabbat identiteitsmerkers van die Joodse ethnos was (Duling 2009:7). Dit is daarom ook nie vreemd dat Paulus in sy hantering van die konflik in bogenoemde gemeentes juis van sy eie etniese herkoms en van etniese taal gebruik maak om hierdie konflikte aan te spreek nie (Duling 2009:8).

\section{Filippense: Etnisiteit tel nie meer nie}

Soos reeds hierbo genoem, het die konflik in Filippense daaroor gegaan dat sekeres in die gemeente (wetsgehoorsame Joodse gelowiges) daarop aangedring het dat die nie-Jode (proseliete)

41.Kyk in hierdie verband Lukas 14:26-27//Matteus 10:37-38; Markus 1:16-20// Matteus 4:18-22//Lukas 5:1-11. Markus 10:29-30//Lukas 18:29-30//Matteus 19:28-29: Markus 8:34//Lukas 9:23//Matteus 16:24; Markus 6:1-6/Matteus 13:5319:28-29; Markus 8:34//Lukas 9:23//Matteus 16:24; Markus 6:1-6/Matteus 13:53-
56; Markus 3:32-35//Lukas 8:20-21//Matteus 12:47-50; Lukas 12:51-53//Matteus 10:34-36 en Lukas 9:57-60//Matteus 8:18-22. 
hulleself moes besny. Agter hierdie versoek lê duidelik die oortuiging dat kind-van-God-wees vir diesulkes met Joodse etnisiteit oorvleuel het, aangesien die besnydenis dié teken was wat die Jodedom van ander ethne onderskei het. In sy verweer teen hierdie mense is dit interessant dat Paulus hom op sy eie etnisiteit (uiterlike dinge) verlaat:

Tog sou ek ook op uiterlike dinge kon vertrou. As iemand meen dat hy nog op uiterlike dinge kan vertrou, ek nog meer: ek is op die agste dag besny, van geboorte ' $n$ Israeliet, uit die stam Benjamin, ' $n$ egte Hebreër, in wetsopvatting was ek ' $n$ Fariseër, in my ywer ' $n$ vervolger van die kerk, in onderhouding van die wet van Moses om vryspraak te verkry, onberispelik.

(Fil 3:4-6, NAV)

Volgens Duling (2009:8) beklemtoon Paulus se verweer vyf Joodse etnisiteitsmerkers: kulturele (godsdienstige) gebruike

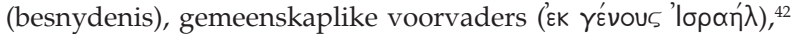
naam (Benjamin), taal (Hebreër) en godsdiens (wet van Moses). Paulus kan dus daarop aanspraak maak dat ook hy deel van die Joodse ethnos is. Wat meer is, op grond van sy eienskappe

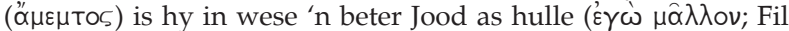
3:4). Hierdie uiterlike dinge (Joodse etnisiteit); hierdie lewe in

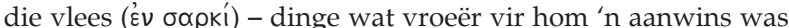
- beskou Paulus egter nou as waardeloos (Fil 3:7) en verwerplik (Fil 3:8): ' ... his main point is that as a Christ believer this ethnicity no longer means anything' (Duling 2009:8; beklemtoning in die oorspronklike). Teenoor dit wat vir hom ' $\mathrm{n}$ aanwins was, stel hy dit wat nou vir hom 'n aanwins is: om Christus Jesus, sy Here, te ken (Fil 3:8, 10), om Christus as enigste bate te kan verkry (Fil 3:8), om een met Christus te kan wees omdat hy glo en daarom vrygespreek kan wees (Fil 3:9), om die krag van Jesus Christus se opstanding te kan ondervind (Fil 3:10), en om deel te kan hê aan Christus se lyding (Fil 3:10). Etnisiteit (kulturele gebruike, gemeenskaplike voorvaders, naam, taal en godsdiens) word dus met die een bate - Christus - vervang. ${ }^{43}$ Wie nie hiertoe bereid is nie, sê Paulus,'soek net hulle eie belange, nie dié van Jesus Christus nie' (Fil 2:21, NAV).

'n Verdere rede hoekom die besnydenis nie nodig is nie, oordeel Paulus, is omdat die Christusgelowiges reeds die ware besnydenis ( om God deur die Gees te aanbid en te dien (Fil 3:3). ${ }^{44}$ Die Christusgelowiges het reeds hierdie gemeenskap met die Gees ervaar (Fil 2:1), en daarom roep Paulus hulle op om eensgesind te wees in liefde, hart en strewe (Fil 2:2). Hulle moet mekaar dien soos Jesus Christus die gestalte van ' $n$ slaaf aangeneem het (Fil 2:7). ${ }^{45} \mathrm{Hy}$ bid dat hulle liefde sal toeneem in begrip en fyn aanvoeling, sodat hulle die dinge sal kan onderskei waarop dit werklik aankom (Fil 1:9). Wat laasgenoemde betref, verwys Paulus waarskynlik hier na die uiterlike dinge (die dinge van die vlees), die besnydenis (Joodse etnisiteit) wat sommiges in die gemeente as so belangrik geag het (Fil 3:3) - dinge waarop dit

42.Paulus se gebruik van $\gamma^{\prime} \varepsilon v o \zeta$ is hier 'n tipiese gebruik van dié term om na die eie groep te verwys (kyk weer voetnoot 3 ).

43.Kyk in hierdie verband die volgende opmerking van Nebradal (2009:34-35): 'Paul's appeal in Phlp 3:5-10 radically supports the view of an all-encompassing and universal Lord above ethnic differences ... the radical to identity is drawn to their dentification with Christ, who form, becoming a slave'

44.Paulus beskryf die besnydenis wat die wetsgehoorsame Jode vereis, as

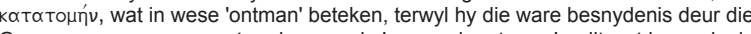
Gees $\pi \varepsilon \rho і т о \mu \eta$ noem, met ander woorde 'om rondom te sny' - dit wat besnydenis in werklikheid is. 'n Ontmande Joodse persoon in die eerste-eeuse Mediterreense wêreld is as permanent onrein beskou, en kon nie in God se teenwoordigheid kom nie. Met die gebruik van hierdie term wil Paulus dus toon dat hulle oproep

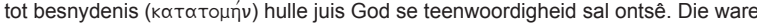

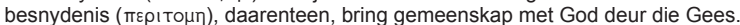

45.In die Mediterreense wêreld is iets soos persoonlike verandering (bv die verandering van etnisiteit) uiters negatief bejeën. Paulus het duidelik verander: ter wille van Christus het hy as Christusgelowige nie meer sy etnisiteit as belangrik wille beskou nie. Om sy statusverandering te regverdig gebruik Paulus die voorbeeld (Malina 1:1). Hiermee regverdig Paulus nie alleen sy eie statusverandering nie, maar roep hy ook implisiet diegene op wat nog aan hulle Joodse etnisiteit vashou om, soos hy, hulle 'status' ter wille van Christus prys te gee. nie werklik aankom nie. As Christusgelowiges (Jood of nie-Jood) behoort hulle nou deur Christus aan God (Fil 1:1), almal het die troos in Christus ondervind (Fil 2:1), en in Christus is hulle nou broers en susters van mekaar (Fil 1:12; 3:1, 13, 17; 4:1, 8, 21; kyk Nebrada 2009:35) - deel van ' $n$ inklusiewe, fiktiewe familie waarin die norm nie etnisiteit is nie, maar liefde en geloof (kyk Bartchy 1999:68-78). Om 'in Christus' te wees hef inderdaad nie etnisiteit op nie - etnisiteit is net nie meer belangrik nie. Geloof (Fil 3:9) en gemeenskap deur die Gees (Fil 2:1) is die norm - nie ' $n$ bepaalde ethnos nie. Dit was, volgens Paulus, die nuwe realiteit in Christus (Hoover 2004:14).

\section{Korintiërs: Wie op iets wil roem, moet in die Here roem}

Soos hierbo aangetoon (kyk § 6.1) was daar in Korinte 'n groep 'apostels', heel waarskynlik Jode. Hierdie apostels het baie klem gelê op die mens se 'menslike liggaam' (2 Kor 10:3, NAV); het die stryd 'met menslike wapens' gevoer (2 Kor 10:3, NAV), hulleself aan hulle eie maatstaf gemeet, en hulleself met hulleself vergelyk (2 Kor 10:12). Wat is hierdie maatstaf dan waarop die 'apostels' so roem deur van menslike wapens gebruik te maak (2 Kor 10:13, 15)? Die antwoord op hierdie vraag lê heel waarskynlik in Paulus se uitspraak in 2 Korintiërs 11:22-23:

Is hulle Hebreërs (taal)? Ek ook. Is hulle Israeliete (naam)? Ek ook. Stam hulle van Abraham af (gedeelde voorgeslag)? Ek ook. Is hulle dienaars van Christus ... ek nog meer! Ek het harder gewerk....

(2 Kor 11:22-23; etnisiteitsmerkers tussen hakies en gekursiveer eie byvoegings)

Duidelik is die maatstaf wat vir hierdie 'apostels' so belangrik was hulle Joodse etnisiteit (menslike liggaam). In hierdie verband maak Paulus van dieselfde argument as in Filippense 3:4-6 gebruik: Sy etnisiteit staan nie ' $n$ duim terug vir die van die

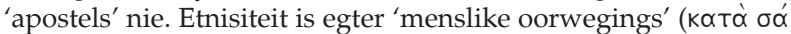
$\rho \kappa \alpha ; 2$ Kor 10:2, NAV) - uiterlike dinge wat tot hooghartigheid lei (2 Kor 10:4-5) en geen grond vir roem is nie. Paulus sou ook daarop kon roem. Hy voldoen immers ook aan dit wat hulle so belangrik ag. Soos hulle oordeel dat hulle aan Christus behoort, kan hy ook (2 Kor 10:7). Wat egter saak maak, is nie menslike eienskappe soos ' $n$ bepaalde etnisiteit nie. Inteendeel: Dit bou die gemeente nie op nie, maar breek dit af (2 Kor 10:8). Wat saak maak, is om nederig en vriendelik te wees (2 Kor 10:1), om in geloof in Christus toe te neem (2 Kor 10:15), aan Hom gehoorsaam te wees (2 Kor 10:6), en met die 'kragtige wapens van God' (2 Kor 10:4, NAV) - die evangelie van God (2 Kor 11:7) - (etniese) vestings te vernietig (2 Kor 10:4). Wie wil roem, moet in die Here roem (2 Kor 10:17), nie op uiterlike eienskappe nie.

\section{Galasiërs: Die wat glo, is almal kinders van Abraham}

Soos hierbo aangetoon, het die konflik in Galasiërs twee redes gehad. Eerstens het wetsgehoorsame Jode, voorstanders van die besnydenis (Gal 2:12), geglo dat nie-Joodse gelowiges die besnydenis moes ontvang (en die wet van Moses moes onderhou; Gal 5:11) om van sonde vrygespreek te word (Gal 2:16). In die tweede plek wou van die Jode nie saam met nie-Jode eet nie (Gal 2:12-13). ${ }^{46}$ Ook in Galasiërs het etnisiteit dus ' $n$ verdelende rol gespeel. $^{47}$

Anders as in Filippense en 2 Korintiërs, verlaat Paulus hom in Galasiërs egter nie op sy Joodse etnisiteit om die konflik in die gemeente te hanteer nie, hoewel hy inderdaad na sy Joodse

46.'Some Jews were afraid that non-Jews never would be totally free of idolatry as long as they had not converted fully to Judaism. While eating together, the Jews would thus be implicated in idolatry. On the other hand, some non-Jews had no patience with Jewish dietary regulations' (Tomson 2005:3).

47.Kyk in hierdie verband Galasiërs 2:14-15 (NAV): 'Jy is 'n Jood, en jy hou jou nie meer aan die Joodse gebruike nie. As jy self leef asof jy nie ' $n$ Jood is nie, hoe kan jy dan mense wat nooit Jode was nie, wil dwing om te lewe asof hulle Jode is? 'Barclay (1988.239) is dus korrek wanneer hy die volgende aanvoer. 'The problem here is not legalism (in the sense of earning merit before God) but cultural imperialism - regarding Jewish identity and the Jewish customs as the essential tokens of membership in the people of God.' 
etnisiteit verwys (vgl Gal 1:13 ['aanhanger van die Joodse leer']; Gal 1:14 ['volksgenote']; Gal 1:14 ['die oorgelewerde leer van my voorvaders']; Gal 2:15 ['Jode van geboorte'], NAV). In Christus het Paulus egter ' $n$ nuwe identiteit gekry deurdat God hom in genade geroep het deur aan hom te verskyn (Gal 1:15-16) en hy tot geloof in Christus Jesus gekom het (Gal 2:16). Hierdie geloof in Christus (en nie die onderhouding van die wet nie; Gal 2:16) spreek die gelowige vry van sonde - laat die gelowige deel kry aan die kruis van Christus (Gal 2:19) en die Heilige Gees (Gal 3:2). Wat meer is: Deur die geloof is almal kinders van Abraham (Gal 3:7).

Anders as om na sy Joodse etnisiteit te verwys (soos in Fil en 2 Kor), is voormelde die argument wat Paulus in Galasiërs gebruik om die gelowiges in die gemeente (Jode en nie-Jode), op hulle nuwe identiteit te wys. Abraham is vrygespreek omdat hy geglo het (Gal 3:6). Abraham se kinders is daarom nie hulle wat deur bloed aan Abraham verbind kan word nie, maar hulle wat glo soos Abraham geglo het (Gal 3:7). Paulus gaan in hierdie

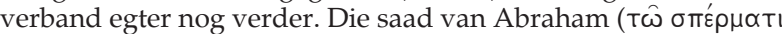

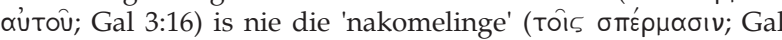
3:16) van Abraham nie, maar een 'nakomeling', naamlik Christus

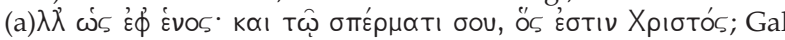
3:16). Die nakomeling van Abraham is dus nie etniese Israel nie, maar Christus self (Duling 2009:9), en wie in Christus glo (soos Abraham geglo het), is almal kinders van Abraham. Daarom maak dit nie saak of iemand Jood of Griek is nie - in Christus is almal een (Gal 3:28). Buell \& Hodge (2004) formuleer bogenoemde argument van Paulus heel akkuraat soos volg:

Paul establishes a kinship for gentiles with Israel that is based not on shared blood but on shared spirit ... an identity marked by a privileged sign of fixity: inclusion in a lineage. Paul constructs a myth of collective identity for his gentiles; they can trace their beginnings not only to their baptism into Christ but also to their ancestor Abraham.

(Buell \& Hodge 2004:245-246)

Taylor (2002) verwoord dit weer só: 'Christocentric identity

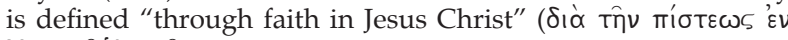
XpıтT⿳' Inooû - Gal 3:26) and the adoption into God's family, with status as children of God and Abraham superseding previous criteria of identity.' In Christus is dit daarom nie meer belangrik of jy besny is of nie (Gal 5:6). Besnydenis beteken om die vryheid in Christus prys te gee, en weer slawe van die wet te word (Gal 2:4). God kyk nie na 'n mens se uiterlike nie (Gal 2:6). Wat wel van belang is, is geloof in Jesus Christus (Gal 2:16; 3:26) wat deur liefde tot dade oorgaan (Gal 5:6), om deur die doop met Christus verenig te wees (Gal 3:27), en deur die Gees van God (wat deur die geloof ontvang is; Gal 3:2-3) beheers te word (Gal 5:16; kyk o a Hays 1996:33). Dít bepaal die identiteit van die kinders van Abraham.

\section{HANDELINGE}

Handelinge is ' $n$ verdere teks in die Nuwe Testament waarin Joodse etnisiteit sterk na vore kom. Daar word byvoorbeeld herhaaldelik verwys na die wet van Moses (kyk o a bv Hand $6: 11,13,14 ; 21: 21,28 ; 25: 8$ ), die (heilige) tempel (kyk bv Hand $5: 25 ; 6: 13,14 ; 21: 27,28 ; 24: 6 ; 25: 8$ ), die besnydenis (kyk o a Hand $7: 8 ; 11: 13 ; 15: 1,5 ; 21: 21)$, Joodse gebruike van die voorvaders (kyk o a Hand 21:21; 26:3; 28:17), die Joodse voorvaders (Hand $3: 13,25 ; 5: 30 ; 7: 12,32$ ), die Jode as volk (kyk o a Hand 10:2 22; 12:11; 21:21, 28), die Joodse land (kyk o a Hand 10:37, 39), die verbond (kyk Hand 3:25; 7:8; 26:6), en die uittog uit Egipte (gedeelde herinneringe; kyk o a Hand 13:17).

Die vraag of nie-Jode ook soos die Joodse gelowiges in die gawes van God kon deel (Jesus Christus, die doop en die lewe; kyk Hand 11:17), kom die eerste keer uitdruklik in die Korneliusvertelling ${ }^{48}$ in Handelinge $10-11$ voor. ${ }^{49}$ Terwyl Petrus in

48.Let op die duidelike beskrywing van Kornelius se etnisiteit in Handelinge 10:1-2 wat land van herkoms (en godsdienstige tradisies, te wete die eet van onrein kos) betref. geesvervoering was, het hy ' $\mathrm{n}$ doek na die aarde sien neerdaal met onrein kos daarin (Hand 10:11-12). In opdrag van die Here wou Petrus egter nie van die kos eet nie, aangesien dit aan die hand van die Joodse reinheidsmaatreëls, onrein was (Hand 10:13-14). God verklaar egter die kos drie keer rein, en wanneer die mans wat Kornelius gestuur het by hom opdaag, beveel God Petrus om saam met hulle te gaan sonder om te 'aarsel' (Hand

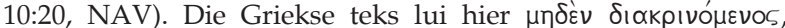
wat eintlik beteken 'sonder om (tussen twee moontlikhede) onderskeid te tref' ${ }^{\prime 0}{ }^{50}$ Die opdrag aan Petrus deur die Gees is dus in wese om te gaan sonder om ' $n$ onderskeid tussen sogenaamde rein en onrein kos of mense te tref (Hand 10:28). Toe Petrus egter in Handelinge 11:1-2 in Jerusalem kom, is hy deur die (Joodse) apostels in Jerusalem 'verwyt' (Hand 11:2, NAV) omdat hy mense besoek het wat nie besny is nie, en selfs saam met hulle

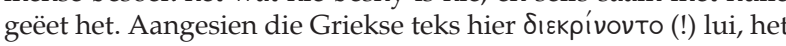
die apostels in wese van Petrus verwag om onderskeid te tref tussen rein en onrein kos, en tussen besnedenes en onbesnedenes. Petrus verdedig egter sy optrede deur te verwys na die opdrag

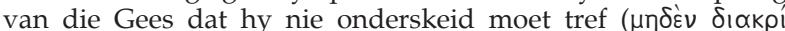
$v \propto v \tau \alpha$; Hand 11:12) tussen rein en onrein kos of mense nie (wat die NAV wéér vertaal met 'dat ek nie moet aarsel nie'). Petrus se verweer kom dus daarop neer dat dit húlle woord teen Gód se woord was, en hulle dus nie verder met hom kon verskil nie.

Hoewel die Jode hiermee tevrede was en God geprys het dat selfs nie-Jode tot inkeer gekom en die lewe ontvang het (sonder om besny te word; kyk Hand 11:18), het die etniese verskille tussen Jood en nie-Jood egter nie gaan lê nie, soos duidelik uit Handelinge 15:1 blyk. Inteendeel: Die vraag of nie-Jode hulle moes laat besny om gered (Christusgelowiges) te kon word, het tot ' $n$ hewige debat tussen Paulus (en Barnabas) en die apostels van die Jerusalem-gemeente gelei (Hand 15:2). In sy toespraak, na die saak bespreek is, stel Petrus God se opdrag uitdruklik in

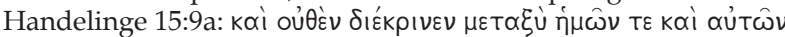
('Hy [God] het geen onderskeid tussen ons en hulle gemaak nie', NAV). Hierdie insig, dat God geen onderskeid op grond van etnisiteit tussen Jood en nie-Jood maak nie, word in Handelinge 15 in Jakobus se toespraak voltrek (Hand 15:13-21): God self het uit die heidennasies (e) $\theta v \omega \hat{v}$; ' $n$ term wat gebruik is om na diegene buite die eie groep te verwys; kyk weer voetnoot 3 ) vir

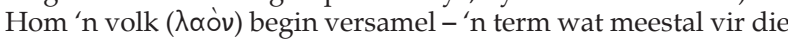
volk van Israel gebruik is.$^{51}$ God sluit in, nie uit nie..$^{52}$ Dít was immers wat die profete lank reeds gesê het (Hand 15:15).

\section{SLOTOPMERKINGS}

Op grond van bogenoemde kan een saak duidelik afgelei word: 'n Eksklusiewe ekklesiologie wat op etniese (kulturele) verskille berus, is op grond van die Nuwe Testament eenvoudig nie moontlik nie. Die Joodse ethnos, wat 'n bepaalde verstaan van God ingesluit het, het persone uit ander ethne uitgesluit ook diegene uit dieselfde ethnos wat nie heilig of heel was nie. Jesus het, in sy begrip van God as 'n God vol medelye, hierdie grense oorgesteek. 'God is ' $\mathrm{n}$ inklusiewe God', was Jesus se deurlopende boodskap in woord én daad. In kontinuïteit met Jesus, het Paulus sonder uitsondering dieselfde evangelie verkondig: Etnisiteit word met geloof in God vervang (Fil 1:1; $2: 1$ ), en die ware besnydenis is die voorreg om God deur die Gees te kan aanbid (Fil 3:3). Om op etnisiteit as maatstaf te roem is ' $n$ lewe in die vlees (2 Kor 10:2), lei tot hooghartigheid (2 Kor 10:4-5), en breek die gemeente (en kerk) af in plaas daarvan om dit op te bou (2 Kor 10:8). Die nakomeling van Abraham is nie etniese Israel nie, maar Christus self, en wie in Christus glo (soos

49.In die volgende gedeelte is onder andere van die insigte van Baker (2009:5-8) gebruik gemaak.

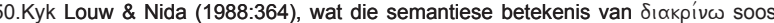
volg beskryf: 'to judge that there is a difference or distinction'.

51.Vergelyk in hierdie verband onder andere Matteus 2:6, Handelinge 12:11 en Handelinge 13:17

52. Kee (1997:140) oordeel dat die insluiting van alle mense by God se volk die sentrale teologiese motief van Lukas-Handelinge is: 'God shows no partiality to sentrale teologiese motief van Lukas-Handelinge is: 'God shows no partiality to
any single group ... the invitation to share in the life of his people extends across all any single group ... the invitation to share in the
humanly defined social lines' (Kee 1997:140). 
Abraham geglo het), is ' $\mathrm{n}$ kind van Abraham. Daarom maak dit nie saak of iemand Jood of Griek is nie - in Christus is almal één (Gal 3:28). Ook Handelinge - die verhaal van die vroegste kerk - toon dieselfde tendens: God maak nie onderskeid tussen 'ons' en 'hulle' nie. Almal is deel van God se volk - of God se volk nou as onsigbare of sigbare kerk (met verskillende denominasies en gemeentes) verstaan wil word. Kortom: 'n Eksklusiewe ekklesiologie kan op geen manier evangelies verantwoord word nie. In die Nuwe Testament word die ekklesiologie juis van enige binding met 'volk' of 'die volk' losgemaak.

Natuurlik kom die geloofsverhouding tussen God en mens altyd kultuur- en taalmatig tot uiting. Taal en kultuur (en etnisiteit, soos dit hierbo beskryf word) bly egter altyd slegs die voertuig van die evangelie op ' $n$ bepaalde plek en tyd. Die versoeking bestaan egter altyd om van etnisiteit self die evangelie te maak, soos dit immers in byvoorbeeld Paulus se gemeentes gebeur het. Dit kan egter nie die maatstaf word as 'almal één in Christus' is nie. Natuurlik beteken dit ook nie dat iemand sy etnisiteit moet versaak om deel van God se volk, 'n bepaalde kerk of gemeente te wees nie. Etnisiteit kan egter nie gebruik word as beginsel vir eksklusiwiteit nie - so ook nie ' $n$ bepaalde verstaan van God wat selfs diegene na aan jou uitsluit nie.

Hieroor was Jesus tog duidelik. Hy het ' $\mathrm{n}$ God verkondig wat lewe gee, lewens verryk en mense verras met sy teenwoordigheid. Hy het 'n God vol medelye verkondig - ' $n$ God wat nooi en insluit. Hy het ' $n$ God verkondig wat heling vir die menslike toestand bring. Hy het van 'n God vertel wat mense se oë, letterlik én figuurlik, geopen het. Hy het $(2$ Kor 10:2) 'n God verkondig wat deur álle grense - hoe belangrik dit ook al vir sommiges is - gebreek het, en elke individu se waarde as belangrik beskou (Macnab 2004:111-115). Dít is wat die kerk, as kerk van Christus, onder andere met woord en daad moet verkondig. Die evangelie is immers inklusief.

\section{LITERATUURVERWYSINGS}

Armstrong, K., 2001, 'Suggestions for a second Axial age', in K. Armstrong, D. Cupitt, R.W. Funk, L. Geering, J.S. Spong \& fellows of the Jesus Seminar (reds.), The once $\mathcal{E}$ future faith, pp. 19-32, Polebridge Press, Santa Rosa.

Bailey, K.E., 2008, Jesus through Middle Eastern eyes: Cultural studies in the gospels, IVP Academic, Downers Grove.

Baker,J.C., 2009, 'Expanding the boundaries: A socio-theological; reading of the inclusion of the non-Judeans in Acts 15', referaat gelewer by die vergadering van die Context Group, Buffalo, New York, 19-21 Maart 2009.

Barclay, J.M.G., 1988, Obeying the truth: A study of Paul's ethics in Galatians, T \& T Clark, Edinburgh.

Barclay, J.M.G., 1996, Jews in the Mediterranean Diaspora: From Alexander to Trajan (323 BCE-117 CE), University of California Press, Berkeley.

Barclay, J.M.G., 2007, 'Constructing Judean identity after 70 CE: A study of Josephus' Against Apion', in Z.A. Crook \& P.A. Harland (reds.), Identity and interaction in the ancient Mediterranean: Jews, Christians and others. Essays in honour of Stephen G Wilson, pp. 99-112, Phoenix Press, Sheffield.

Barth, F. (red.), 1969, Ethnic groups and boundaries: The social organization of cultural difference, Little, Brown and Company, Boston.

Brown, R., 2000, Group processes, Blackwell Publishing, Oxford.

Buell, D.K. \& Hodge, C.J., 2004, 'The politics of interpretation: The rhetoric of race and ethnicity in Paul', JBL 123(2), 235251.

Carter, W., 2006, The Roman Empire and the New Testament: An essential guide, Abingdon, Nashville.

Cohen, S.J.D., 1999, The beginnings of Jewishness: Boundaries, varieties, uncertainties, University of California Press, Berkeley.

Cromhout, M., 2007, Jesus and identity: Reconstructing Judean ethnicity in $Q$, Cascade Books, Eugene.
Cupitt, D., 2001, 'Reforming Christianity', in K. Armstrong, D. Cupitt, R.W. Funk, L. Geering, J.S. Spong \& fellows of the Jesus Seminar (reds.), The once $\mathcal{E}$ future faith, pp. 51-64, Polebridge Press, Santa Rosa.

De Vos, G., 1975, 'Ethnic pluralism: Conflict and accommodation', in G. de Vos \& L. Romanucci-Ross (reds.), Ethnic identity: Cultural continuities and change, pp. 5-41, Mayfield, Palo Alto.

Douglas, M., 1966, Purity and danger: An analysis of concepts of pollution and taboo, Praeger, New York.

Duling, D.C., 2005, 'Ethnicity, ethnocentrism, and the Matthean ethnos', BTB 25, 125-143.

Duling, D.C., 2008, 'Race, ethnicity, and nationalism', ongepubliseerde kamee.

Duling, D.C., 2009, 'Ethnicity and Paul's letter to the Romans', referaat gelewer by die vergadering van die Context Group, Buffalo, New York, 19-21 Maart 2009.

Esler, P.F., 2002, 'Jesus and the reduction of intergroup conflict', in W. Stegemann, B.J. Malina \& G. Theissen (reds.), The social setting of Jesus and the gospels, pp. 185-205, Fortress Press, Minneapolis.

Esler, P.F., 2003a, 'Social identity, the virtues, and the good life: A new approach to Romans', BTB 33, 51-64.

Elser, P.F., 2003b, Conflict and identity in Romans: The social setting of Paul's letter, Fortress Press, Minneapolis, Minnesota.

Geertz, C., 1963, 'The integrative revolution', in C. Geertz (red.), Old societies and new states, pp. 108-113, Free Press, New York.

Gelardini, G., 2009, 'Religion, ethnicity, and ethnoreligion: Trajectories of a discourse in German-speaking historical Jesus scholarship', voordrag gelewer by die kongres Neuestes vom Neuen Testament: Wie plural, kontrovers, normativ sind die antiken Impulse für die moderne christliche Existenz? (Internationales Neutestestamentlertreffen), Evangelische Akademie, Tutzing, 12-14 Junie 2009.

Hall, J.M., 1997, Ethnic identity in Greek antiquity, Cambridge University Press, Cambridge.

Hanson, K.C. \& Oakman, E.1998, Palestine in the time of Jesus: Social structures and social conflicts, Fortress Press, Minneapolis.

Hays, J.B., 1996, The moral vision of the New Testament: A contemporary introduction to New Testament ethics, HarperCollins, New York.

Herzog, W.R., 2005, Prophet and teacher: An introduction to the historical Jesus, Westminster John Knox, Louisville.

Holland, D., Lachicotte, W., Skinner, D. \& Cain, C., 2003, Identity and agency in cultural worlds, Harvard University Press, Cambridge.

Hoover, R.W., 2004, 'The art of gaining \& losing everything', in Jesus Seminar, The historical Jesus goes to church, pp. 11-30, Polebridge Press, Santa Rosa.

Hutchinson, J. \& Smith, A.D., 1996, Ethnicity, Oxford University Press, Oxford.

Jenkins, R., 1997, Rethinking ethnicity: Arguments and explorations, Sage, Thousand Oaks.

Kee, H.C., 1997, To every nation under heaven: The acts of the apostles, Trinity Press International, Harrisburg.

Lieu, J.M., 2004, Christian identity in the Jewish and Graeco-Roman world, Oxford University Press, Oxford.

Louw, J.P., \& Nida, E.A., 1988, Greek-English lexicon of the New Testament based on semantic domains. Volume 1: Domains, National Book Printers, Goodwood.

Macnab, F., 2004, 'Preaching the new faith', in Jesus Seminar, The historical Jesus goes to church, pp. 105-121, Polebridge Press, Santa Rosa.

Malina, B.J., 1981, The New Testament world: Insights from cultural anthropology, John Knox, Louisville.

Malina, B.J., 1986, Christian origins and cultural anthropology: Practical models for Biblical interpretation, John Knox, Atlanta.

Malina B.J., 1989, 'Dealing with biblical (Mediterranean) characters: A guide for US consumers', BTB 19(4), 127-141.

Malina B.J., 2001, The social gospel of Jesus: The kingdom of God in Mediterranean perspective, Fortress Press, Minneapolis. 
Malina, B.J. \& Neyrey, J.H., 1991a, 'First-century personality: Dyadic, not individualistic', in J.H. Neyrey (red.), The world of Luke-Acts: Models for interpretation, pp. 67-96, Hendrickson, Peabody.

Malina, B.J., 1991b, 'Honor and shame in Luke-Acts: Pivotal values of the Mediterranean world', in J.H. Neyrey (red.), The world of Luke-Acts: Models for interpretation, pp. 25-65, Hendrickson, Peabody.

Malina, B.J. \& Pilch, J.J., 2006, Social science commentary on the letters of Paul, Fortress, Minneapolis.

Malina, B.J. \& Rohrbaugh, R.L., 1992, Social science commentary on the Synoptic Gospels, Fortress, Minneapolis.

Mason, S., 2007, 'Jews, Judaeans, Judaizing, Judaism: Problems of categorization in ancient history', JSJ 38, 457-512.

Nagel, J., 1994, 'Constructing ethnicity: Creating and recreating ethnic identity and culture', Social Problems 41(1), 152-176.

Nebrada, S.R., 2008, 'Have this in mind': A socio-scientific reading of Philippians 2:5-11, unpublished PhD-thesis, University of Pretoria, Pretoria.

Neusner, J., 1979, 'Map without territory: Mishnah's system of sacrifices and sanctuary', HR 19, 103-127.

Neyrey, J.H., 1991, 'The symbolic universe of Luke-Acts: “They turn the world upside down"', in J.H. Neyrey (red.), The world of Luke-Acts: Models for interpretation, pp. 271-304, Hendrickson, Peabody.

Patterson, J.P., 2004, 'If you give a mouse a cookie ... What the quest holds in store for the church', in Jesus Seminar, The historical Jesus goes to church, pp. 31-42, Polebridge Press, Santa Rosa.

Pilch, J.J., 1997, "'Are there Jews and Christians in the Bible?"', HTS Teologiese Studies/Theoligical Studies 53(1\&2), 119-125.
Roosens, E., 1994, 'The primordial nature of origins in migrant ethnicity', in H. Vermeulen \& C. Govers (reds.), The anthropology of ethnicity: Beyond 'ethnic groups and boundaries', pp. 81-104, Spinhuis, Amsterdam.

Schermerhorn, R.A., 1978, Comparative ethnic relations, Random House, New York.

Shils, E., 1957, 'Primordial, personal, sacred and civil ties', British Journal of Sociology 8, 130-145.

Smith, A.D., 1986, The ethnic origins of nations, Blackwell Oxford.

Spong, J.S., 2001, 'A Christianity for tomorrow: The vision of a new Reformation', in K. Armstrong, D. Cupitt, R.W. Funk, L. Geering, J.S. Spong \& fellows of the Jesus Seminar (reds.), The once $\mathcal{E}$ future faith, pp. 65-80, Polebridge Press, Santa Rosa.

Tajfel, H., 1982, 'Social psychology of intergroup relations', Annual Review of Psychology 33, 1-39.

Tajfel, H., 1986, 'The social identity theory of intergroup conflict', in S. Worchel \& W.G. Austin (reds.), Psychology of intergroup relations, pp. 7-24, Nelson-Hall, Chicago.

Taylor, N.H., 2002, 'Conflicting bases of identity in early Christianity: The example of Paul', in A.J. Blasi, P.A. Turcotte \& J. Duhaime (reds.), Handbook of early Christianity: Social science approaches, pp. 577-598, Altamira Press, Walnut Creek.

Tomson, P.J., 2005, Presumed guilty: How the Jews were blamed for the death of Jesus, Meinema, Zoetermeer.

Turner, J.C., 1999, 'Some current issues in research on social identity and self-categorization theories', in N. Ellemers, R. Spears \& B. Doosje (reds.), Social identity: Context, commitment, content, pp. 6-34, Blackwell, Oxford.

Van den Berghe, P.L., 1987, The ethnic phenomenon, Praeger, Westport. 